\title{
BUSINESS PLAN - MANAGEMENT TOOL OF THE ENTREPRENEUR
}

\author{
Nicoleta Ciucescu \\ "Vasile Alecsandri" University of Bacau \\ ciucnico@yahoo.com
}

\begin{abstract}
This paper proposes to highlight the importance of developing of a business plan, which is an indispensable tool for any entrepreneur, aims to reduce the degree of uncertainty in entrepreneurial activity, to reduce the company's environmental vulnerability. Thus the objectives of the paper consist on presentation of the concept define, the role, the functions of the business plan, also the typology, the stages concerning the preparation and the content. of $i t$. The research method was to use a comparative study of the specialty literature. The business plan represents a logical flowchart of action, which involves perspective on thinking on a business, starting from certain objectives, helping to create an overall picture of the whole business. Basically it covers all stages and resources which will be necessary to an entrepreneur to achieve the proposed objectives in a predetermined time period. The business plan offers the possibility to assess the chances of success of businesses, representing a means to control for the entrepreneur on profitability and business viability through a systemic analysis of a comprehensive set of rigorously structured information, providing thereby the knowing of all aspects involved in business and the effective and in depth preparing.
\end{abstract}

\section{Keywords}

entrepreneur; businesses; goals; profitable; success

\section{JEL Classification}

M13; M21

\section{Introduction}

We live in a society where there is an increasingly hard competition, in which any company, to be considered performant, must meet a number of conditions, and have a certain model of organization and economic activity. The development of contemporary society is characterized by a highly dynamic evolution, causing changes not only in terms of the size of the enterprises, the degree of concentration and complexity of economic activities, but also in relation of the companies with their economic and social environment, with the market. Launching in business is a very important step for an entrepreneur, because the risk of failure is high in the early years. Involvement in an established business and its development enjoys a greater chance of success due to the decrease of the degree of uncertainty. All these suggest that entrepreneurs need to create a business plan. In this context the existence of a competitive business plan, anchored in the current economic reality, might make the difference between success and failure.

\section{What is the business plan}

The transition to a market economy has imposed reconsideration of economic activity in terms of profitability and competitiveness. The development of business activity after the fulfillment of these two concepts involves also the use of tools to foreshadow 
the results of the initiated actions. The business plan is a symbol of a new vision and approach specific to the market economy, based on identifying and harnessing of economic opportunities.

The business plan is one of the most used tools to harness economic opportunity in the current period, there are many theoretical and practical approaches on this. The business plan is approached in several ways, the most widespread being practical definitions, from the position of a manager or of an entrepreneur.

In the specialty literature, the business plan has been defined by various authors. West (2000) considers the business plan as "a tool of the present, developed through successive approximations, using the experience and the achievements of the past to design a realistic way forward. It has as aim the most advantageous and workable compromise between what is desired and what the company can do." The team coordinated by Turcu (2008) believes that "the business plan is a method of designing and promoting of a new business or of a significant development of an existing business, starting from the identification of an economic opportunity, through which are determined the objectives to be fulfilled, are dimensioned and structured the main necessary resources and activities, demonstrating that it is profitable and that it deserves to be supported by potential investors."

According to Săndulescu (2006) the business plan is "a document which makes known the existing resources and developing prospects of a company and invites in this way, the support and the cooperation of potential supporters (entrepreneurs, lenders and investors)."

Other approaches treat the business plan in terms of management science. From a management segment view, Nicolescu (2000) consider the business plan as a "dynamic decision tool, designed, on the one hand, to managers within the company in order to increase the efficiency of their work and, on the other hand, to investors, bankers and, generally, to any possible industrial, commercial, social partner, to whom it enable them to be informed of the perspectives of this business."

So as Longenecker, Moore and Petty has shown (2003), in the paper Small Business Management - An Entrepreneurial Emphasis, business plan is defined as "a written document reflecting the development prospects of a newly created business."

So as Zimmerer and Scarborough, (2005) in the paper Essentials of Entrepreneurship and Small Business Management, a business plan is seen as "a summary of a business idea, which includes operational and financial details, opportunities and marketing strategies and, also, skills and managerial capacities of the entrepreneur. The business plan also describes the direction the company is heading, which are its objectives, where you want to reach and, especially, the methods of achieving the objectives."

In my vision, the business plan is a document that includes the objectives and how to achieve them, and the resources necessary to achieve the set objectives, developed with the aim of directing business activity, to a position in the market and profit.

\section{The role and the functions of the business plan}

\subsection{The role of the business plan}

The role of a business plan is complex and consists in demonstrating viability of the business that are expected, but also to guide the entrepreneur in running the necessary activities to achieve the set objectives. Therefore, the business plan should be considered not as a form or document to be completed at the request of potential donors, but as a complex system based on the interdependence of resources, activities and operations, and which reflects in an accessible manner to the reader the business what it is intended to be conducted and the positive (profitable) development of it in time. 
The role of a business plan is to guide the entrepreneur since the first year of running the business and to demonstrate that the business deserves to be funded. Its implementation means control and adjustment in function of actual development. This control exercised over the business development will cover all critical elements of the economic entity (stocks, costs of production, sales, payments). It is not however a passport for financing, but a way of highlighting the entrepreneurship flair and spirit, the promoted business idea. As stated by Badea (2005) the business plan is a written document that describes the nature of the business, the target-market, the advantages that business will have on the competitors and the resources and skills available to business owners. For its preparation is necessary to carefully consider the offered products / services, the competition, the necessary financial resources and other operational details.

However, the business plan is a working tool used to start and run a business that requires material, financial and human resources. This means that the business plan is used as an effective planning tool and as a mean of allocation and control of resources. Through it is harnessed the experience and achievements from the past in order to build the future by the most appropriate methods of estimation and approximation. The business plan is a management tool designed to reduce the degree of uncertainty in the day to day activity of small and medium companies, thereby reducing their vulnerability to the environment.

According to the authors Barsky and Catanach (2005) "business plan performs several roles, including:

- determine the field in which the company operates or will to carry out its various activities;

- determine the objectives that company proposes in every field of activity;

- formulate some hypotheses about market conditions, sales, finance, human resources in which the company will act;

- determine and implement of company's strategies;

- estimate some obstacles and risks that may arise during the course of activities."

According to Kotler (2001) "a business plan pursues 3 objectives. Firstly, it serves to formulate strategies and to transmit them to higher levels of management. Secondly, it is a supporting element of the application for financing the activity and, thirdly, it is a tool for tracking the evolution of the company and making the necessary corrections during its implementation."

Ionescu (2004) believes that essentially "a business plan can serve as:

1. an action plan;

2. a route map for the company;

3. a selling tool."

According to Porojan (2007) "a business plan can serve as an action plan to help setting in motion" a business that the entrepreneur was considering for a long time. Once the business was launched, a business plan is a valuable tool to keep the business on track in the desired direction, so it can be considered a route map for the company. Considered as one of the most important roles, the business plan can serve as a selling tool that is the tool that is needed to convince financiers (creditors or investors) to provide the necessary support."

\subsection{The functions of the business plan}

The speciality literature has identified several functions that performs business plan. In this regard, the team led by Bişa (2005) believes that "business plan has as basic functions:

1. function of effective communication tool, of transfer of ideas, of proposal of plans, especially to financial institutions. 
2. function of management tool, reference framework in exercising managerial functions, by coordinating business activities, the development of coherent predictions.

3. function of measure and control. The business plan allows evaluation, permanent comparison of the obtained results with the proposed objectives and, on this base, taking the right decisions.

4. function of establishing the financing needs, the fundraising and repayment of borrowed amounts."

\section{Typology of business plan}

The typology of the business plan is based on a number of criteria identified by experts in the field, such as: the form of the business plan, the goal of preparation, according to direct interested persons, the size and the degree of detailing.

In terms of the form, business plans may be established either in a form of a document produced professionally, to be used, for example, for obtaining the financing, either in the form of a manuscript that serves as documentation for goals, objectives and company's strategies. As a document for internal use, it is no need to have a special graphic form, nor to be bound, being sufficient the filing.

The team coordinated by Radu (2004), believes that "in terms of the purpose for which is drawn up, the business plan can be:

- a management tool for analysis, implementation, supervision and control of the business;

- a means of communication with the economic environment to attract funds."

According to Nicolescu (2001) "as a communication tool with the economic environment, the business plan is drawn up for:

- $\quad$ starting a new business;

- making an investment;

- obtaining a loan;

- conclusion of strategic alliances;

- $\quad$ achieving a merger;

- obtaining selling contracts."

The business plans are developed for a specific public, interested in how is running the activity of a company. In this regard, Ursachi (2005) notes that "given the fact that the interests of those directly involved differ, and the results can not satisfy everyone equally, we can distinguish different types of business plans based on the directly interested persons:

- confidential business plan for a restrained audience (for example, senior management, major shareholder or, with some amendments, a potential buyer of the company);

- partly business plan for either investors or financiers, who want to know the business prospects, focusing on cash flow and capital structure, or for some specific reader (managers of regional or national branches) who want detailed and realistic indications for decision making;

- business plan without confidential informations, for a general information, destined, for example, to shareholders, financial analysts, customers, suppliers, researchers."

According to Săndulescu (2006), in terms of size and degree of detailing, you can create several types of business plans, depending on the development stage of the company and the set objectives, as follows:

- a summary business plan fits best to the companies which do not have a long standing, being in an early stage of development. 
- $\quad$-a business plan more widespread and became traditional is the business fully plan, developed in 10 to 20 pages, which presents with more details the operations and future projects of the company in question.

- in the case of well-established companies, a business plan can be an important guide to management by ensuring all managers to understand the directions of action of the company and their role in achieving goals. In this case, it is appropriate to draw up an operational business plan, detailed, developed in over 20 pages. More the level of detailing is great, more sure is the fact that the managers understand their role and how to bring out all actions, pending final goals.

\section{The stages of preparation of the business plan}

\subsection{The stages of preparation of the content of the business plan}

A business plan can be compared to a road map, because it shows where the company is and where it wants to go. The business plan includes milestones and other props for guiding in the environment in which the company activates, also preparing the trader for less predictable changes of the "route".

In preparing a business plan there are not patterns to suit all companies, although some goals or functions are common. The business plans must describe the products / services to be sold, the available market for this or the market that will be created for these, must show how services will be provided etc., all in a compelling, clear and concise form.

Preparing a business plan is a dynamic phenomenon, which is in a permanent improvement, because the potential funding sources may like to see improvements of the plan, new ideas and the latest figures. However, the business plan must be reviewed and updated at least annually.

Regarding the process of preparing a business plan is obvious that it requires a specific sequence of operations. Thus, Bessis et alli (1997) believes that "for preparing a business plan it is necessary to follow the following three steps:

- collection of information (prices, competitors, suppliers, technical data of achievement / performance of services, juridical data etc.);

- actual planning of the activity, choosing the right strategy and finding ways to achieve the set goals. Business plan design requires to contractors to agree on the degree of detailing in which the preparing of the final plan. This level of detailing will result otherwise, partly, from the size and maturity of the company, and from the given goal of the business plan;

- drafting the plan (stage of choosing of the optimal form to presentation of the result of the previous stage).

If it does not pay enough attention to these stages of preparing a business plan then more than likely that recipients of the business plan will treat in a similar manner what is presented to them as a business plan."

\subsection{The content of the business plan}

What must include a business plan and how to prepare a business plan are important issues that must adapt to the goal for which it was developed. The main areas that need to cover a business plan are in short: business, market, management and finance. According to Burduş (2005), "the content of the business plan consists of information on:

a) the business (the company, the field of activity, the objectives);

b) the market (the customer, the product, the market segmement, the competition);

c) the management (the organization, the management, the staff); 
d) the finance (the income, the expenditure, the sources and the use of funds, the financial previsions)."

The team coordinated by Turcu (2008) believes that "A business plan should highlight the strengths of the companies against the competitors and, at the same time, to assess realistically the difficulties they might face. The investors must be persuaded that many inherent business risks were identified and can be controlled. The plan structure includes:

a) the synthesis of the business plan;

b) the presentation of the company;

c) the products and the services of the company;

d) the marketing program and the sales plan;

e) the development plan of the products and the services;

f) the program of operational activities;

g) the management of the activities;

h) the financial plan;

i) the final offer or entrepreneurial business plan;

j) the annexes."

Regarding the drafting of the business plan should take into account certain requirements, such as:

- $\quad$ the written pages not to be in great numbers;

- $\quad$ the presentation to be done clearly and with references to sources used in an objective manner;

- the style to be fair, simple, clear, precise, and the phrase to have a single meaning;

- the presentation of the facts from the past and the future evolution of business to be done chronologically;

- $\quad$ to be well organized, logical, precise, shapely and to highlight the essentials;

- to have a nice aspect;

- $\quad$ to be printed in a sufficient number of copies.

\section{Conclusions}

From the study of the specialty literature we can draw some conclusions on the preparation and the importance of a business plan.

The business plan is a means of self-edification for those who order and carry out the business plan on the profitability and viability of the entrepreneurial approach regarding the harness of an economic opportunity. Through a systematic analysis of a broad set of informations, that are rigorously structured, using certain methods and techniques, it ensures a deeper knowledge of the issues involved by the harness of the economic opportunities.

The business plan is a tool for prevision of the business in that business, in the sense that in the business plan are established the objectives to be achieved, the duration and the sequence of the necessary activities, the size of the allocated resources and the marketing, financial, technical, personnel and management main parameters to be considered.

The business plan represents a basis for organizing, coordinating and controlling the processes involved in the entrepreneurial approach to harness the economic opportunity. Thus, starting from previsioned objectives and from the activities outlined, it is established organizational system configuration. Later, simultaneously and after the putting into operation of the organizational system, it begins to be used the elements incorporated in the business plan and for the goal to coordinate the decisions and the actions of the staff implicitly. It is essential that all modes of organization, coordination and control, with important role in ensuring the 
functionality of organization, to be organically subordinated to the achievement of the previsions included in the business plan.

The business plan is the most complete and effective tool for entrepreneurs.

In order that the business plan to be operational there must be a coherence between the decisions taken at different levels by finding a balance between the current management of the company and its strategic options. This fact does not mean that the business plan cannot be changed due to real opportunities, but only after a reassessment of the new situations and after a detailed assessment of the new directions the company could turn thanks to the harness of these opportunities.

\section{References}

Badea, F. (2005), Managementul producţiei, Editura ASE, Bucureşti.

Barsky, N. P., Catanach, A. H. Jr. (2005), Management accounting: a business planning aproach, Editura Houghton Mifflin, Boston.

Bessis, J., Galați, D., Hiller, L., Kienast, P. (1997), Planul de afaceri. Cum să concepi şi să redactezi un plan de afaceri, Editura Ştiinţă şi Tehnică, Bucureşti.

Bişa, C. (coord.), (2005), Elaborarea studiilor de fezabilitate şi a planurilor de afaceri, Editura BMT, Bucureşti.

Burduș, E. (2005), Tratat de management, Editura Economică, Bucureşti.

Ionescu, V. C. (2004), Managementul firmelor mici și mijlocii, Editura Economică, Bucureşti.

Kotler, Ph. (2001), Managementul marketingului, Editura Teora, Bucureşti.

Longenecker, G. J., Moore, C. J., Petty, W. (2003), Small Business Management - An Entreprenorial Emphasis, Editura South Western, USA, Ohio.

Nicolescu, O. (2000), Sisteme, metode şi tehnici manageriale ale organizaţiei, Editura Economică, Bucureşti.

Nicolescu, O. (2001), Managementul întreprinderilor mici şi mijlocii, Editura Economică, Bucureşti.

Porojan, D. (2007), Planul de afaceri: concepte, metode, tehnici, proceduri, Editura Irecson, București.

Radu, V. (coord.), (2004), Planul de afaceri, Editura Mărgăritar, Bucureşti.

Săndulescu, I. (2006), Planul de afaceri. Ghid Practic (Modele de referinţă), Ediţia a III-a, Editura C.H. Beck, București.

Turcu, O., et alli (2008), Management, Editura Alma Mater, Bacău.

Ursachi, I.(2005), Management, Editura ASE, București.

West, A.( 2000) Planul de afaceri, Editura Teora, Bucureşti.

Zimmerer, T. W., Scarborough, N. M. (2005), Essentials of Entrepreneurship and Small Business Management, Editura Englewood Cliffs, Prentice Hall. 